\title{
PERAN EMPOWERING LEADERSHIP DALAM MENINGKATKAN PRODUKTIVITAS KARYAWAN SELAMA WORK FROM HOME
}

\author{
aTina Rahayu, aNailil Muna \\ aUniversitas Muria Kudus, ${ }^{b}$ Politeknik Kudus \\ tina.rahayu@umk.ac.id
}

\begin{tabular}{l|l|l} 
Received : September & Accepted : October & Published: December
\end{tabular}

\begin{abstract}
ABSTRAK
Peran Empowering Leadership Dalam Meningkatkan Produktivitas Karyawan Selama Work From Home. Kebijakan Work Fom Home (WFH) di masa pandemi belakangan ini menimbulkan banyak dilema bagi organisasi terkait keberhasilan kinerjanya atau tidak. Penelitian ini bertujuan untuk menganalisis hubungan antara Work from home (WFH) dan Computer-mediated communication (CMC) dengan produktivitas yang didukung dengan pemberdayaan kepemimpinan sebagai mediasi. Sampel penelitian ini adalah 89 responden yang termasuk dalam kelompok pekerja milenial. Pengambilan sampel menggunakan purposive sampling dengan alat analisis SmartPLS 3. Hasil penelitian menunjukkan bahwa kepemimpinan yang memberdayakan mampu memediasi hubungan antara WFH dan CMC dengan meningkatkan produktivitas pekerja milenial. Fleksibilitas yang ditawarkan oleh WFH dan kenyamanan CMC serta dukungan intens dari para pemimpin dapat meningkatkan produktivitas.
\end{abstract}

Kata Kunci: Work From Home, Computer-Mediated Communication, Empowering Leadership, Produktivitas.

\section{ABSTRACT}

The Work from home policy during the recent pandemic has created many dilemmas for organizations regarding the success of their performance or not. This study aims to analyze the relationship between Work from home (WFH) and Computer-mediated communication (CMC) with productivity supported by empowering leadership as mediation. The sample of the research is 89 respondents who belong to the millennial worker group. Sampling used purposive sampling with the SmartPLS 3 analysis tool. The results showed that empowering leadership was able to mediate the relationship between WFH and CMC by increasing the productivity of the millennial workers. The flexibility offered by WFH and the convenience of CMC as well as intense support from leaders can increase productivity.

Keywords: Work from home, Computer-Mediated Communication, Empowering Leadership, Productivty.

\section{PENDAHULUAN}

Indonesia tengah dilanda wabah pandemi COVID-19 pada Maret 2020 hingga sekarang ini menyebabkan kondisi ekonomi tidak stabil karena berubahnya regulasi dan keadaan di beberapa sektor industri. Wabah ini menahan laju perkembangan usaha bisnis yang menyebabkan melemahnya sektor ekonomi. Semua perusahaan harus menerapkan social distancing sesuai kebijakan pemerintah dengan memberlakukan sistem Work Form Home (WFH) untuk meminimalisir dan memutus rantai penyebaran COVID-19. Kebijakan ini tentunya menuai berbagai reaksi baik reaksi positif maupun keraguan apakah WFH bisa diterapkan secara efektif karena penerapannya mendadak sehingga fasilitas penunjangnya kurang memadai. Perlu adanya dukungan pemimpin dan koordinasi antar semua karyawan 
serta dibutuhkan berbagai softskills yang dapat membantu proses berjalannya bekerja secara jarak jauh. Selain itu, situasi kerja dan rancangan kerja harus segera dirubah secara strategis sehingga semua kolaborasi yang baru tersebut dapat meningkatkan produktifitas kerja.

Sebelum adanya kasus Pandemi COVID19 ini, sebenarnya WFH merupakan bagian dari tren HR Practices yang sedang berlangsung. WFH dinilai menjadi solusi bagi pekerja millennial yang menginginkan fleksibilitas kerja untuk mendapatkan Work-Life Balance. Bekerja secara WFH memungkinkan pemenuhan kebutuhan leisure karena jam kerja yang bebas dan fleksibel tanpa mengurangi produktifitas. Bermain game sejenak serta aktif di social media pada jam kerja secukupnya dapat menjadi hal yang dibutuhkan selama WFH. Penelitian menemukan bahwa pekerjaan yang disertai dengan leisure dapat mempengaruhi kreativitas (Dahlin et al. 2004, Lakhani \& Wolf 2005, Jeppesen \& Lakhani 2010, Von Hippel 1988, De Jong et al 2010, Barrington \& Harrington 1981, Madjar et al 2002).

Untuk mencapai keberhasilan produktivitas karyawan selama WFH, maka diperlukan dukungan kemampuan softskill seperti kemampuan dalam komunikasi jarak jauh, koordinasi dan rapat secara virtual atau bisa disebut Computer-mediated communication (CMC). CMC adalah ketika dua atau beberapa orang didalamnya hanya dapat saling berkomunikasi atau bertukar informasi melalui komputer yang termasuk ke dalam teknologi komunikasi baru (Pratiwi, 2014). CMC adalah salah satu softskill yang sangat penting di era digital dan kondisi pandemi seperti dengan tren bekerja secara jarak jauh. Karyawan yang memiliki kemampuan berkomunikasi secara virtual ini dinilai mampu meningkatkan kinerja mereka walaupun tidak dilakukan bersama-sama di kantor. Hal ini tentunya juga harus didukung oleh pemimpin yang tetap bisa memberdayakan bawahannya walaupun tidak bertemu secara langsung di kantor.

Bentuk dorongan pemimpin bisa disebut dengan empowering leadership yang ditengarai mengedepankan pola hubungan yang harmonis antara pimpinan dan bawahan untuk menumbuhkan pemberdayaan yang mengarah pada kreativitas dan inovasi (Zhang dan Bartol, 2010). Pemimpin mempunyai tantangan baru di era pandemi saat ini untuk terus mampu memberdayakan karyawannya secara jarak jauh. Upaya ini dilakukan agar kinerja karyawan selama bekerja dari rumah dapat meningkat karena adanya motivasi dari pemimpin mereka untuk selalu mengedepankan produktivitas kerja mereka. Semua karyawan harus siap beradaptasi dengan segala lingkungan yang cepat berubah saat ini sehingga semuanya harus saling berkoordinasi dengan baik agar perusahaan dapat terus bertahan di era pandemi Covid-19 saat ini.

Efektifitas WFH masih terjadi pertentangan di kalangan akademisi. Beberapa peneliti menyatakan bahwa WFH dapat meningkatkan produktifitas karena para karyawan memiliki keseimbangan pekerjaan dengan keluarga yang baik dan peningkatan kreatifitas (Timbal and Mustabsat, 2016). Sebaliknya Bloom (2014) mengklaim bahwa karyawan yang bekerja di luar kantor (WFH) sebenarnya tidak bekerja karena dinilai mengurangi hasil dan kualitas kerja. Google dan Hewlett Packard juga mencoba mengurangi pekerjaan dari rumah (Pathak etal, 2015, hal12). Sehingga dengan adanya fenomena gap yang terjadi pada saat pandemi dan research gap, maka penelitian ini bertujuan untuk menganalisis apakah sistem kerja WFH dan Computer-Medited Communication dapat meningkatkan produktivitas kerja melalui empowering leadership selama Pandemi Covid-19 pada karyawan milenial di Kota Kudus Jawa Tengah. Pada seksi berikutnya akan disajikan kajian literatur yag diikuti penjelasan mengenai metode dan pengukuran. Hasil penelitian kemudian dipresentaskan, didiskusikan dan disimpulkan.

\section{KAJIAN LITERATUR}

\section{Work From Home (WFH)}

Teknologi yang semakin canggih saat ini memungkinkan mendukung pekerjaan dari rumah. Banyak teknologi yang berdampak signifikan terhadap pekerjaan, memudahkan dan mengotomisasi beberapa pekerjaan sehingga lebih efisien dan efektif. Dengan beberapa 
kemudahan yang ditawarkan melalui penggunaan teknologi tinggi, WFH tentu dapat dilakukan dengan efektif tanpa mempengaruhi tingkat kinerja. Saat ini, pekerjaan telah berubah menjadi Pekerjaan telah berubah menjadi aktivitas tanpa batas yang harus dilakukan kapan saja dan di mana saja (Kurland dan Bailyn, 1999).

WFH banyak diperdebatkan tentang kefektifan dan keberhasilannya. Grant et al (2013) menyebutkan bahwa aspek positif dari kerja jarak jauh dapat diringkas sebagai peningkatan produktivitas, kemampuan untuk bekerja secara fleksibel dan dari lokasi yang berbeda, dalam batasan temporal jam berbasis kantor dan dalam beberapa kasus mengurangi tingkat stres dan kesejahteraan yang lebih baik. Sebaliknya ada juga efek negatifnya seperti intensifikasi kerja dengan akses ke teknologi 24/7 yang mengarah ke jam kerja yang panjang, dengan sedikit jeda dari pekerjaan, perilaku duduk banyak meningkat dengan godaan untuk bekerja lebih lama dikomputer dan menyebabkan masalah fisik. Oleh sebab itu, keberhasilan WFH harus dimonitor dan didukung oleh semua lini manajemen sehingga dapat mencapai keberhasilan pada target pekerjaan.

Keseimbangan pekerjaan dan rumah juga perlu diperhatikan selama WFH. Ada beberapa penelitian yang menunjukkan bahwa pekerja jarak jauh dapat bekerja lebih lama (Harker, Martin dan MacDonnell, 2012). Karyawan bervariasi dalam cara mereka menjaga pekerjaan dan aktivitas di luar pekerjaan terpisah atau tumpang tindih (Clark,2000). Karyawan yang menyukai integrasi pekerjaan dan aktivitas rumah lebih cenderung menyukai batas yang lebih lemah. Sehingga intensitas pekerjaan justru lebih lama daripada bekerja dari kantor. Penelitian Williams (2020) menyatakan bahwa jam kerja di Amerika Serikat meningkat 40 persen atau setara 3 jam lebih lama daripada waktu bekerja di kantor sebelumnya. Selain itu, Larson (2020) juga mengemukakan penyebab lain menurunnya produktivitas selama WFH. Pertama, kurangnya pengawasan terhadap pekerja sehingga menyebabkan hilangnya motivasi kerja. Kedua, banyaknya distraktor yang membuat pekerja kehilangan fokus untuk bekerja. Ketiga, sering terjadi miskomunikasi. Keempat, masalah keamanan data. Untuk itu, karyawan yang bekerja dari rumah harus memiliki manajemen batas sehingga bisa mengurangi tingkat stres selama WFH.

\section{Computer-Mediated Communication (CMC)}

Computer-mediated communication (CMC) didefinisikan sebagai komunikasi dimediasi oleh komputer yang saling berhubungan, antara individu atau kelompok yang dipisahkan dalam ruang atau waktu (Luppicini, 2007) dan termasuk pertukaran email, pesan instan, video langsung, chatting, dan penggunaan situs jejaring sosial seperti Whatsapp, facebook, dan lainnya. CMC erat kaitannya dengan sosial media dengan fitur komunikasi yang canggih. Komunikasi dalam urusan pekerjaan di era teknologi sekarang ini sangat mendukung tercapainya koordinasi antar tim dengan jarak yang sangat jauh. Para karyawan dapat melakukan rapat melalui zoom atau google meet, melakukan koordinasi melalui grup whatsaap, saling kirim tugas melalui email dan sejenisnya. Teknologi komunikasi yang canggih ini dapat dimanfaatkan perusahaan untuk melakukan pekerjaan dimanapun dan kapanpun sehingga koordinasi bisa dicapai walaupun tidak sedang berada di kantor.

Beberapa penelitian telah menunjukkan interaksi antara komunikasi online dan offline (misalnya Boyd \& Ellison, 2009; Ellison, Steinfield, \& Lampe, 2007), dan CMC tetap meningkat. Penelitian Tolmie dan Boyle (2000) menyatakan bahwa pengenalan email ke dalam lingkungan belajar dapat meningkatkan komunikasi yang efektif antara mahasiswa dan dosen. Hal ini tentunya dapat diterapkan pada dunia kerja sehingga memungkinkan komunikasi yang efektif tanpa tatap muka secara langsung.

\section{Empowering Leadership}

Empowering leadership menurut Zhang dan Bartol (2010) adalah pemimpin yang mampu memberdayakan kemampuan bawahannya untuk memimpin dirinya sendiri dan bertanggung jawab terhadap tindakan dirinya sendiri. Empowering leadership juga merujuk pada pemimpin yang dapat memotivasi bawahannya, memberikan contoh yang baik dalam bekerja sehingga bawahan akan merasa bangga, percaya diri, memiliki loyalitas yang tinggi, dan berbuat lebih baik dari sebelumnya. Dapat dikatakan bahwa seseorang yang memiliki 
gaya empowering leadership berarti pemimpin yang mampu berperan sebagai agen perubahan dan mampu mentransformasikan perubahan organisasi ke arah yang lebih baik. (Bruce, 1998; Pamela et al., 2012) menambahkan bahwa secara keseluruhan, fungsi kepemimpinan adalah mampu memerankan agen perubahan. Pemimpin organisasi harus dapat bertindak sebagai agen perubahan bagi anggota-anggotanya (Jones et al., 2005).

Li et al. (2016) dan Zhou et al. (2018) menyebutkan bahwa empowering leadership juga menyediakan lebih besar otonomi pengambilan keputusan kepada karyawan, yang sebagai hasilnya merasa pekerjaan mereka dihargai, sehingga meningkatkan efikasi diri dan harga diri mereka. Ketika karyawan memiliki pemimpin yang memberdayakan serta mendukung pekerjaan mereka dengan baik motivasi mereka akan semaking tinggi untuk mencapai hasil yang baik pula. Pemimpin seperti inilah yang tentunya sangat dibutuhkan pada saat semua stakeholder bekerja dari jarak jauh. Motivasi dan dukungan penuh dari pemimpin dapat memberikan energi positif untuk setiap individu melakukan pekerjaan mereka dengan maksimal dimanapun mereka bekerja.

\section{Produktivitas}

Produktivitas sering dikaitkan dengan kuantitas pekerjaan yang dihasilkan. Produktivitas juga mengacu pada rasio output terhadap rasio input fisik. Sauermann (2016) menyatakan bahwa produktivitas kerja dapat ditentukan melalui tujuan atau sasaran yang objektif, perbandingan karyawan dengan waktu, kualitas, dan kontrol atas hasil dan fasilitas bagi karyawan. Produktivitas mengacu pada bagaimana menghasilkan atau meningkatkan hasil barang dan jasa yang setinggi-tingginya dengan memanfaatkan sumber daya secara efisien. Sehingga produktivitas menjadi salah satu tolak ukur keberhasilan suatu organisasi dari segi tujuan, rencana dan efisiensi penggunaan sumber daya, serta kualitas yang unggul.

\section{Pengembangan Hipotesis}

WFH sebenarnya dinilai mendukung strategi perusahaan dalam mencapai transformasi digital karena menciptakan upaya kolaboratif dalam menghasilkan pekerjaan, menciptakan pola pikir yang lebih cepat serta mengembangkan kompetensi digital dengan berbagai platform yang tersedia. Tetapi tantangannya adalah para pekerja harus memiliki kompetensi soft skill yang mendukung mereka melakukan pekerjaan dari rumah. Menurut Grant et al (2013) aspek positif dari kerja jarak jauh dapat meningkatkan produktivitas mengurangi tingkat stres dan kesejahteraan yang lebih baik. Penelitian Narpati et. al (2021) menunjukkan bahwa bekerja dari rumah dapat meningkatkan produktivitas karyawan. Bekerja di rumah membuat kedekatan secara psikologi antara pekerja dengan anggota keluarga sehingga dapat memberikan dorongan yang positif untuk bekerja.

\section{H1: WFH berpengaruh positif signifikan terhadap produktivitas.}

Komunikasi dan koordinasi merupakan kunci utama dalam menyelesaikan pekerjaan dari rumah. Dengan bekerja secara bebas, pekerja dituntut menumbuhkan kompetensi automasi serta kelincahan bekerja sehingga tetap memiliki produktifitas yang tinggi. Konsep WFH yang dapat memberikan segala kemudahan dan meningkatkan produktifitas pekerja harus diimbangi dengan berbagai kompetensi soft skill sebagai bekal para pekerja untuk melakukan pekerjaan dari rumah. CMC merupakan salah satu softskills yang harus dimiliki oleh karyawan. Mereka harus mampu berkomunikasi dengan baik sehingga tercapai pemahaman antar satu sama lain dan koordinasi tim dalam bekerja berhasil. Konsep CMC juga hampir sama dengan teleworking, yaitu istilah yang digunakan untuk menggambarkan pekerjaan yang menggunakan teknologi komunikasi untuk bekerja dari jarak jauh (Nilles, 2007). Komunikasi jarak jauh merupakan gambaran dari komunikasi melalui komputer atau alat komunikasi digital yang berbasis internet. Kossek et al (2006) dalam studi profesional teleworking menemukan bahwa otonomi yang lebih besar melalui kerja jarak jauh menyebabkan lebih jarang terjadinya depresi pada wanita. Komunikasi jarak jauh dikatakan 
berhasil jika pemahaman dan kesepakatan bisa terjadi sehingga pekerjaan bisa diselesaikan bersama-sama sehingga meningkatkan produktivitas individu maupun tim.

$\mathrm{H} 2$ : CMC berpengaruh positif signifikan terhadap produktivitas.

Selain keberhasilan WFH dan dukungan dari keberhasilan komunikasi jarak jauh, motivasi dan dorongan dari pemimpin juga sangat penting untuk mencapai sebuah pencapaian produktivitas yang maksimal. Karyawan yang merasakan dukungan yang lebih tinggi dari pemimpin lebih cenderung mengalami pemberdayaan yang lebih besar ( Amor et al., 2020; Kwon and Kim, 2020; Spreitzer, 1996 ). Studi di rumah sakit, hubungan antara staf perawat dan pemimpin, aksesibilitas ke sumber daya lain dan suasana kerja yang kondusif untuk otonomi perawat akan secara signifikan mendukung dan meningkatkan kepuasan kerja dan kinerja perawat staf ( Andrews et al. , 2012 ; Cowden et al. , 2011; Orgambidez dan Almeida, 2020). Kepuasan kerja yang dirasakan oleh adanya pemerdayaan yang baik dari pemimpin ini tentunya dapat mempengaruhi peningkatan produktivitas karyawan selama WFH. Pemimpin bisa memberikan otonomi yang lebih luas untuk mengatur pekerjaan mereka secara fleksibel tetapi memastikan bahwa pekerjaan mereka sesuai dengan target yang telah ditentukan.

Selain itu, pemimpin yang memberdayakan karyawannya dengan mendorong untuk mengupgrade softskills mereka akan menciptakan semangat baru dan memberikan ruang untuk menciptakan kreativitas karyawan melalui kemudahan teknologi dan akses infromasi selama bekerja dari rumah. Pemimpin dapat memberdayakan karyawan untuk membuat atau mempertahankan batasan yang sesuai dengan preferensi pribadi untuk integrasi atau segmentasi pekerjaan dan aktivitas rumah. Kecocokan yang baik antar pemimpin dan karyawan akan membantu organisasi mendapatkan manfaat dari peningkatan produktivitas dan retensi staf (Harker Martin dan MacDonnell, 2012). Pemberdayaan dari pemimpin selama WFH, didukung oleh komunikasi jarak jauh yang baik akan menciptakan inovasiinovasi yang dapat menciptakan keunggulan kompetitif organisasi. Seperti penelitian Srithongrung (2011) yang menyimpulkan bahwa kepemimpinan transformasional dan budaya inovatif memiliki pengaruh signfikan terhadap kinerja karyawan.

H3: Empowering leadership memediasi hubungan antara WFH dan produktivitas.

H4: Empowering leadership memediasi hubungan antara CMC dan produktivitas.

\section{Gambar 1. Gambar Penelitian}

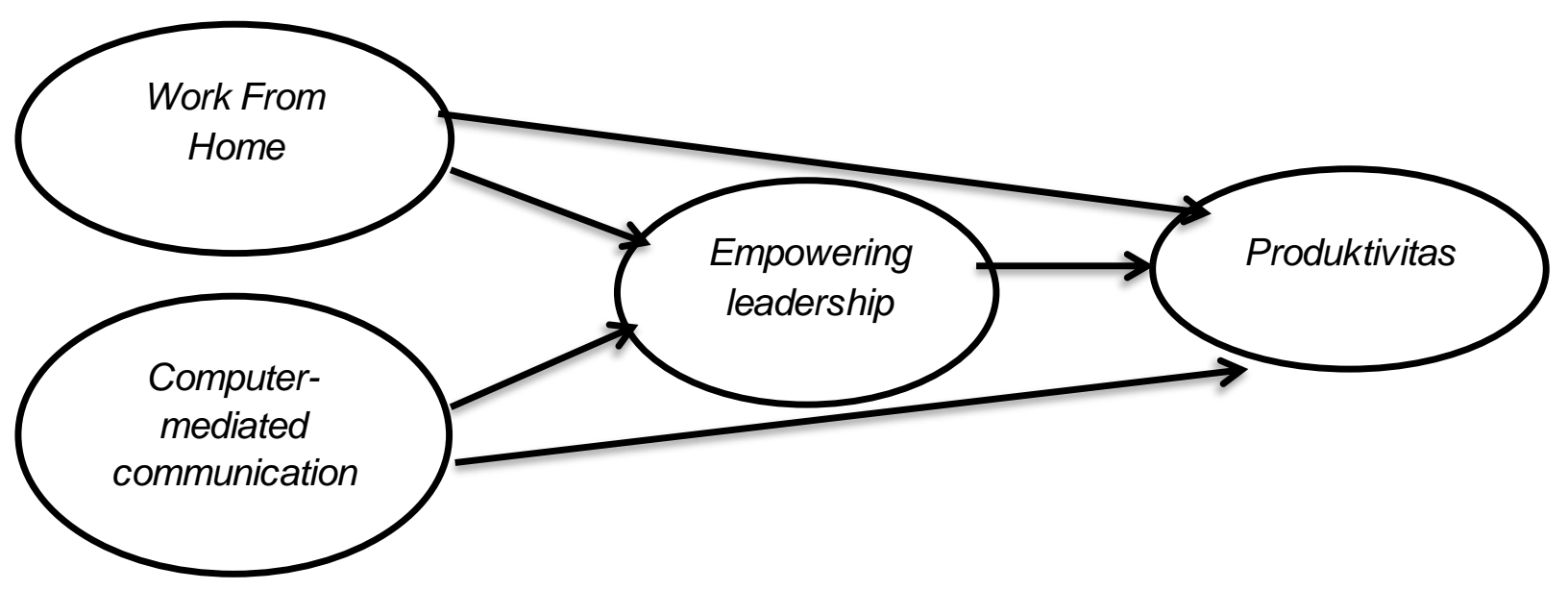




\section{METODE}

Jenis penelitian ini adalah penelitian eksplanatory dengan pola hubungan kausalitas. Cohen et. al (2013) mendefinisikan penelitian eksplanatory yaitu penelitian untuk mengetahui alasan di balik terjadinya fenomena tertentu dan menjelaskan situasi atau masalah dalam bentuk hubungan. Objek dan populasi yang digunakan dalam penelitian ini adalah para pekerja milenial di Kota Kudus yang tidak diketahui jumlahnya. Sampel yang digunakan dalam penelitian ini adalah para pekerja kategori millenial di Kota Kudus yang tidak diketahui jumlahnya. Generasi millennial yaitu orang yang lahir dari 1980 hingga 2004, yang berusia 17 hingga 41 tahun pada 2021 (Weinbaum, Girven, \& Oberholtzer, 2016). Generasi milenial dipilih karena mereka termasuk digital native yang mana lahirnya sesudah ada teknologi sehingga dinilai mampu menggunakan teknologi secara fasih untuk melakukan pekerjaan.

Data diperoleh dari penyebaran kuesioner melalui google form yang dikirim ke beberapa pekerja milenial di Kudus. Dalam menentukan jumlah sampel yang representatif adalah tergantung pada jumlah indikator dikali 5 sampai 10 (Ferdinand, 2006). Sehingga jumlah msampel di penelitian ini adalah sebanyak 65 responden $(17 \times 10=130)$. Dari 130 kuesioner yang disebar, hanya 89 kuesioner (68\%) yang sesuai dengan kualifikasi penelitian. Teknik pengambilan sampel yang digunakan dalam penelitian ini adalah purposive sampling dimana Pengambilan sampel ini memperhatikan karakteristik populasi sehingga keterwakilan sampel (Rahi, 2017). Karakteristik sampel responden adalah pekerja milenial yang berumur antara 17-41 tahun, bekerja secara WFH saat pandemi, pendidikan minimal SMA, dan minimal bekerja selama 6 bulan.

WFH diukur dari 3 item diantaranya Lingkungan kerja yang bebas dan fleksibel, Jam kerja yang fleksibel, dan menggunakan teknologi digital dalam bekerja (Farrell, 2017). Pengukuran CMC diadopsi dari (Merdian and Warrior, 2015) sebanyak 3 item yaitu komunikasi melalui social media groups (email, facebook, Whatsapp, instagram), komunikasi melalui virtual meetings (zoom, google meet), dan dapat berdiskusi dengan baik melalui platform online atau komunikasi virtual. Empowering leadership diukur dengan 4 item yang diadopsi dari (Ahearne, Mathieu, and Rapp, 2005) diantaranya meningkatkan makna kerja, mendorong partisipasi dalam pengambilan keputusan, mengekspresikan keyakinan dalam kinerja tinggi, dan memberikan otonomi dari kendala birokrasi. Variabel produktivitas diukur dari 3 item yaitu adanya target atau sasaran kerja harus objektif, adanya ketersediaan fasilitas dalam bekerja bagi pekerja, dan adanya hasil kerja yang sesuai dengan kualitas (Sauermann, 2016).

Analisis yang digunakan dalam penelitian ini adalah berbasis Structural Equation Model (SEM) dengan menggunakan software SmartPLS 3.0.

\section{HASIL DAN PEMBAHASAN}

Data demografi responden dalam penelitian ini meliputi umur responden dalam kategori milenial (antara umur 19-38 tahun), pendidikan dan lama bekerja. Data lebih lengkapnya dapat dilihat pada Tabel 1. 
Tabel 1.

Demografi Responden

\begin{tabular}{|c|c|c|}
\hline $\begin{array}{l}\text { Detail } \\
\text { Total Sample (89) }\end{array}$ & Total & $\%$ \\
\hline \multicolumn{3}{|l|}{ Age } \\
\hline $\begin{array}{l}<20 \text { tahun } \\
20-24 \text { tahun }\end{array}$ & $\begin{array}{c}1 \\
46\end{array}$ & $\begin{array}{c}1,12 \\
20,08\end{array}$ \\
\hline 25-29 tahun & 32 & 35,96 \\
\hline 30-34 tahun & 7 & 7,87 \\
\hline$>35$ tahun & 3 & 3,37 \\
\hline Total & 89 & 100 \\
\hline \multicolumn{3}{|l|}{ Education } \\
\hline SMA & 23 & 25,84 \\
\hline D3 & 5 & 5,62 \\
\hline S1 & 49 & 55,06 \\
\hline S2 & 12 & 13,48 \\
\hline Total & 89 & 100 \\
\hline \multicolumn{3}{|l|}{ Length of Work } \\
\hline$<1$ tahun & 17 & 19,10 \\
\hline 1-3 tahun & 53 & 59,55 \\
\hline 4-6 tahun & 14 & 15,73 \\
\hline$>6$ tahun & 5 & 5,62 \\
\hline Total & 89 & 100 \\
\hline
\end{tabular}

Sumber: Data yang diolah

Penelitian ini menggunakan Partial Least Squares (PLS) untuk menganalisis model penelitian dengan bantuan software SmartPLS 3. Pendekatan PLS berbasis varians lebih disukai daripada metode berbasis kovarians, karena PLS memberlakukan lebih sedikit batasan pada ukuran sampel dan distribusi . Meskipun prediksi pengukuran dan parameter struktural terjadi secara bersamaan, aplikasi model PLS biasanya terjadi dalam dua tahap. Langkah pertama adalah menilai model pengukuran menggunakan analisis faktor konfirmatori . Ini juga memperkirakan reliabilitas dan validitas konstruk teoritis. Kemudian, langkah kedua adalah mengestimasi pengujian model struktural dari asosiasi (jalur) antar hipotesis dalam model penelitian ini.

Untuk menentukan keandalan suatu model pengukuran, metode yang paling umum digunakan adalah mengukur konsistensi internalnya. Konsistensi internal model pengukuran ini diukur dengan menggunakan metode yang diusulkan Fornell dan Larcker (1981), keandalan komposit (CR), alpha Cronbach dan varians rata-rata diekstraksi (AVE). Nilai cronbach's alpha atau composite reliability harus $>0,7$ dikatakan memiliki nilai reliabilitas yang baik, namun nilai 0,6-0,7 masih dapat diterima untuk penelitian yang bersifat explanatory (Ghozali, 2014). Hasil evaluasi model PLS Algoritma run 1 menunjukkan bahwa beban luar lebih dari 0,70 . Artinya semua indikator dari semua vaiabel valid sehingga tidak ada indkator yang perlu dihilangkan. Hasil pengujian menunjukkan bahwa model pengukuran cukup reliabel (Tabel 2). 
Tabel 2.

Measurement Model Evaluation

\begin{tabular}{|c|c|c|c|c|c|c|}
\hline \multirow{2}{*}{$\begin{array}{l}\text { Latent } \\
\text { variable }\end{array}$} & \multirow{2}{*}{ Items } & \multicolumn{2}{|c|}{$\begin{array}{c}\text { Convergent } \\
\text { Validity }\end{array}$} & \multicolumn{2}{|c|}{$\begin{array}{c}\text { Internal Consistency } \\
\text { Reliability }\end{array}$} & \multirow{2}{*}{$\begin{array}{c}\begin{array}{c}\text { Discriminant } \\
\text { Validity }\end{array} \\
\text { HTMT <1 }\end{array}$} \\
\hline & & $\begin{array}{l}\text { Loadings } \\
\quad>0,7\end{array}$ & $\begin{array}{l}A V E \\
>0,5\end{array}$ & $\begin{array}{c}\text { Composite } \\
\text { Reliability } \\
>, 6\end{array}$ & $\begin{array}{c}\text { Cronbach } \\
\text { Alpha }>0,7\end{array}$ & \\
\hline \multirow{3}{*}{$\begin{array}{l}\text { Work from } \\
\text { home }\end{array}$} & WFH1 & 0,869 & \multirow{3}{*}{0,684} & \multirow{3}{*}{0,867} & \multirow{3}{*}{0,773} & \multirow{3}{*}{ Yes } \\
\hline & WFH2 & 0,818 & & & & \\
\hline & WFH3 & 0,793 & & & & \\
\hline \multirow{3}{*}{$\begin{array}{c}\text { Computer- } \\
\text { Medited } \\
\text { Communication }\end{array}$} & CMC1 & 0,912 & \multirow{3}{*}{0,835} & \multirow{3}{*}{0,938} & \multirow{3}{*}{0,901} & \multirow{3}{*}{ Yes } \\
\hline & CMC2 & 0,946 & & & & \\
\hline & CMC3 & 0,882 & & & & \\
\hline \multirow{4}{*}{$\begin{array}{l}\text { Empowering } \\
\text { leadership }\end{array}$} & EL1 & 0,820 & \multirow{4}{*}{0,695} & \multirow{4}{*}{0,901} & \multirow{4}{*}{0,852} & \multirow{4}{*}{ Yes } \\
\hline & EL2 & 0,778 & & & & \\
\hline & EL3 & 0,836 & & & & \\
\hline & EL4 & 0,896 & & & & \\
\hline \multirow{3}{*}{ Produktivitas } & $\mathrm{P} 1$ & 0,896 & \multirow{3}{*}{0,684} & \multirow{3}{*}{0,938} & \multirow{3}{*}{0,901} & \multirow{3}{*}{ Yes } \\
\hline & $\mathrm{P} 2$ & 0,916 & & & & \\
\hline & P3 & 0,928 & & & & \\
\hline
\end{tabular}

Sumber: Data yang diolah

Untuk menentukan validitas divergen model, digunakan metode Fornell dan Larcker (1981). Metode ini didasarkan pada perbandingan akar kuadrat dari AVE dan sisa korelasi antar variabel laten. Validitas divergen menguji apakah konstruk tersebut berbeda atau tidak. Jika akar kuadrat dari AVE lebih tinggi dari korelasi dual-mode lainnya, akan ada validitas divergen yang baik antara konstruksi. Tabel 3 menunjukkan bahwa validitas diskriminatif berlaku untuk model, karena akar kuadrat dari AVE untuk setiap konstruk lebih tinggi daripada korelasi antara konstruk variabel.

Tabel 3.

Fornell-Larcker Criterion

\begin{tabular}{lllll}
\hline & WFH & CMC & EL & Prod \\
\hline WFH & 0,827 & & & \\
\hline CMC & 0,582 & 0,914 & & \\
\hline EL & 0,645 & 0,822 & 0,833 & \\
\hline Prod. & 0,673 & 0,664 & 0,761 & 0,913 \\
\hline
\end{tabular}

Sumber: Data yang diolah

Koefisien determinasi (Tabel 4) digunakan untuk mengukur kemampuan konstruk eksogen (WFH dan CMC) dalam menjelaskan variabel endogen (empowering leadership dan produktivitas). Chin (1998) menetapkan tiga nilai untuk $\mathrm{R}^{2}$ yaitu $0,19,0,33$, dan 0,67 sebagai nilai kecil sedang dan besar. Dalam penelitian ini, $\mathbf{R}^{2}$ untuk variabel empowering leadership menunjukkan nilai yang besar $(0,718)$ sedangkan variabel produktivitas menunjukkan nilai yang sedang $(0,580)$ dalam mempresiksi model. Artinya, bahwa variabel eksogen (WFH dan CMC) mampu menjelaskan variabel eksogen (empowering leadership) 
sebanyak 71,8\%. Sedangkan variabel ekesogen (empowering leadership) mampu menjelaskan variabel endogen (produktivitas) sebanyak 58\%, sedangkan sisanya dipengaruhi oleh faktor lain yang tidak termasuk dalam penelitian ini.

Tabel 4. Koefisien Determinasi

\begin{tabular}{lcc}
\hline \multicolumn{1}{c}{ Variables } & R Square & R Square Adjusted \\
\hline Empowering leadership & 0,718 & 0,711 \\
\hline Produktivitas & 0,580 & 0,575 \\
\hline Sumber: Data yang diolah & &
\end{tabular}

Pengujian hipotesis dalam penelitian ini menunjukkan bahwa semua hipotesis diterima yang bisa dilihat pada tabel 5. Path coefficient menunjukkan hubungan yang signifikan antar variabel di semua hipotesis. WFH dan CMC terbukti mampu meningkatkan produktivitas yang ditunjukkan dengan nilai path coefficient yang positif masing-masing sebesar 0,192 dan 0,515 dengan signifikansi di bawah 0,05. Hal ini sesuai dengan penelitian Narpati et. al (2021) yang menunjukkan bahwa WFH dapat meningkatkan produktvitas kerja. Variabel EL juga terbukti mampu memediasi hubungan antara WFH dan CMC terhadap peningkatan produktvitas yang ditunjukkan oleh nilai path coefficient yang positif masing-masing 0,192 dan 0,515 dengan tingkat signifikansi di bawah 0,05. Hasilnya menunjukkan bahwa mediasinya adalah mediasi parsial yang ditunjukkan dengan nilai yang signifikansi di semua hipotesis.

\section{Tabel 5. Path Coefficient}

\begin{tabular}{lccccc}
\hline & $\begin{array}{c}\text { Path } \\
\text { Coefficients }\end{array}$ & $\begin{array}{c}\text { Standart } \\
\text { Deviation }\end{array}$ & T Statistics & P-value & Result \\
\hline $\mathrm{H} 1: \mathrm{WFH} \rightarrow$ Prod & 0,192 & 0,066 & 2,889 & $0,004^{*}$ & Diterima \\
\hline $\mathrm{H} 2: \mathrm{CMC} \rightarrow$ Prod & 0,515 & 0,068 & 7,590 & $0,000^{*}$ & Diterima \\
\hline $\mathrm{H} 3: \mathrm{WFH} \rightarrow \mathrm{EL} \rightarrow$ Prod & 0,192 & 0,066 & 2,889 & $0,004^{*}$ & Diterima \\
\hline $\mathrm{H} 4: \mathrm{CMC} \rightarrow \mathrm{EL} \rightarrow$ Prod & 0,515 & 0,068 & 7,590 & $0,000^{*}$ & Diterima \\
\hline
\end{tabular}

Note: * $P$-value $<0,05$.

Sumber: Data yang diolah

Penerapan kebijakan kerja dari rumah demi memutus rantai penyebaran Covid-19 memiliki dampak yang berbeda-beda tiap individu. Hasil wawancara dari salah satu pekerja yang bekerja dari rumah mengatakan bahwa WFH dirasakan dapat meningkatkan kinerja mereka karena waktu yang felksibel dan kondisi hati yang rileks, tetapi mereka merasa bahwa bekerja selama 24 jam selama 7 hari sehingga waktu antara bekerja dan santai di rumah memiliki batas yang sangat tipis. Hal ini sesuai dengan penelitian Calrk (2000) yang menyebutkan bahwa pekerjaan yang dilakukan dari rumah mengalami tumpang tindih dengan aktivitas di luar kerja. Dari sisi organisasi, salah satu hasil wawancara dengan pemimpin organisasi yang menerapkan sistem WFH menunjukkan bahwa selama kebijakan WFH, para karyawan dinilai lebih menikmati pekerjaan mereka dan mengurangi stress kerja karena faktor fleksibilitas yang sangat tinggi. Hal ini sesuai dengan penelitian Crosbie \& Moore (2004) yang menyebutkan bahwa fleksibilitas kerja dari rumah dapat menghasilkan keseimbangan hidup yang lebih baik. Tetapi survei yang dilakukan oleh McKinsey (Afriyadi, 2020) dan YouGov \& USA Today (Schrotenboer, 2020) melaporkan fakta yang berbeda, dimana WFH justru dapat menurunkan produktivitas kerja sebesar 25 persen. Hal tersebut terjadi salah satunya karena WFH sering membuat para pekerja harus melakukan pekerjaannya di sepanjang waktunya tanpa henti. Hasil penelitian ini menunjukkan bahwa WFH secara signifikan meningkatkan produktivitas kerja dalam organisasi yang salah satunya didukung oleh fleksibilitas kerja terkait waktu dan tempat. 
Kebijakan WFH secara teknis dan prosedur tentunya tidak bisa dilakukan secara langsung karena terpisah jarak sehingga komunikasi yang baik menjadi salah satu faktor penting demi terjalinnya kerjasama yang sukses. Komunikasi yang efektif di masa pandemi sekarang ini tentunya harus didukung dengan adanya sumber internet dan alat digital untuk memenuhi kebutuhan koordinasi antar individu melalui berbagai platform media sosial dan aplikasi-aplikasi lain atau biasa disebut dengan computer-mediated communication. Penggunaan CMC menjadi sangat sering dan hampir semua orang bisa mengadakan rapat dimanapun dan kapanpun berada. $\mathrm{H} 2$ menunjukkan bahwa alat digital yang menyediakan kebutuhan komunikasi dan rapat virtual terbukti sangat memberikan dampak yang baik untuk peningkatan produktivitas. Kuesioner terbuka pada responden menyebutkan bahwa media yang sering digunakan untuk berkomunikasi dalam bekerja adalah WhatsApp, Telegram Zoom, dan Google Meet. Choudhury et. al, (2020) menyatakan bahwa secara geografis memberikan fleksibilitas pekerja dan pilihan untuk tinggal di mana saja dapat mempengaruhi produktivitas. Moran (2016) menyatakan bahwa komunikasi yang dimediasi secara digital dapat memperluas peluang pencarian kerja. Ini termasuk dapat digunakan untuk berkomunikasi untuk pekerjaan yang diselesaikan saat bekerja dari jarak jauh. Komunikasi yang termediasi tentunya memudahkan individu untuk berkoordinasi dan berbagi tugas sehingga meningkatkan efektivitas.

Keberhasilan WFH di dunia kerja harus didukung oleh pemimpin yang dapat memberdayakan bawahannya sehingga diperlukan pengawasan dan dukungan berupa motivasi bagi karyawan. Sebagaimana penelitian Forsyth (2010) menunjukkan bahwa produktivitas kerja individu dapat menurun karena kurangnya motivasi kerja dan sulitnya berkoordinasi dalam tim. Untuk meminimalkan kegagalan kinerja selama WFH, para pemimpin dapat mempertahankan produktivitas dengan membagi anggota tim menjadi tim yang lebih kecil (Forsyth, 2010). Dengan begitu, setiap anggota akan lebih mudah berkoordinasi dalam tim kecil. Hasil penelitian $\mathrm{H} 3$ dan $\mathrm{H} 4$ menunjukkan bahwa pemberdayaan kepemimpinan dapat memediasi hubungan antara WFH dan CMC dengan produktivitas. Pemimpin yang bisa lebih memberdayakan, mendukung, dan memotivasi bawahannya selama WFH terbukti mampu meningkatkan produktivitasnya.

Penelitian (Mann dan Holdsworth, 2003, Sullivan, 2003, Mirchandani, 2000) tentang WFH menunjukkan dampak negatif pada hubungan keluarga antara pasangan dan anakanak, di mana konflik dapat terjadi antara peran pekerjaan dan rumah. Sehingga peran pemimpin sangat dibutuhkan untuk membantu hal tersebut dengan memberikan arahan dan dukungan. Penggunaan CMC yang efektif juga dapat meminimalisir kesalahpahaman antar anggota tim atau individu sehingga koordinasi kerja dapat diselesaikan lebih cepat. Seperti yang Kossek et al (2006) lihat bahwa teleworking dapat memberi perempuan lebih banyak fleksibilitas untuk mengelola pekerjaan mereka, menghasilkan tingkat kesejahteraan yang lebih besar sebagai konsekuensi dari kehadiran mereka dalam pekerjaan dan kehidupan keluarga. Memberikan kesempatan kepada karyawan tentang cara bekerja selama WFH dan mengundang diskusi tentang strategi pengambilan keputusan dinilai dapat meningkatkan motivasi karyawan untuk menyelesaikan pekerjaan lebih cepat. Sehingga kepemimpinan yang memberdayakan terbukti mampu meningkatkan produktivitas kerja karyawan selama WFH.

\section{SIMPULAN}

Hasil penelitian ini menunjukkan bahwa individu yang bekerja dengan sistem WFH dan melakukan pekerjaannya dengan dukungan CMC dapat meningkatkan produktivitasnya melalui dukungan yang intens dari pemimpin. Pemberdayaan pemimpin dinilai mampu mensukseskan pekerjaannya selama WFH. Fleksibilitas kerja dan dorongan partisipasi pengambilan keputusan menjadi salah satu motivasi bagi individu untuk berkembang dan berkreasi dalam menyelesaikan pekerjaannya. Perbedaan individu yang satu dengan yang lainnya dalam menjalankan tugas tentunya juga akan menghasilkan output yang beragam yang menjadikan karya tersebut penuh dengan inovasi. Ini bisa menjadi keuntungan tersendiri selama komunikasi jarak jauh efektif. CMC yang efektif dapat mendukung kinerja 
individu dalam sebuah tim untuk menghasilkan ide-ide yang beragam dan tentunya mendapat dukungan penuh dari pemimpin karena mereka sepenuhnya percaya pada tuntutan tugas masing-masing individu. Terakhir, dikatakan bahwa pemberdayaan kepemimpinan dapat memediasi hubungan antara WFH dan CMC dengan produktivitas.

Implikasi yang dapat diterapkan oleh berbagai organisasi adalah bahwa pemimpin yang dapat memberdayakan karyawan sangat diperlukan dalam segala situasi dan kondisi lingkungan bisnis yang beragam dan tidak dapat diprediksi. Kebijakan baru dari pemerintah, seperti kondisi kasus Covid-19 yang melonjak, mungkin dapat segera diatasi jika pimpinan dapat memberikan pemahaman kepada pegawai tentang efektifitas dan makna pekerjaannya serta dapat menjadi contoh yang baik sebagai motivasi pegawai. untuk terus berkembang dalam segala kondisi.

\section{REFERENSI}

Ahearne, M., Mathieu, J., \& Rapp, A. 2005. "To empower or not to empower your sales force? An empirical examination of the influence of leadership empowerment behavior on customer satisfaction and performance." Journal of Applied Psychology, 90: 945-955

Amor, A.M., Vazquez, J.P.A. and Faíña, J.A. 2020. "Transformational leadership and work engagement: exploring the mediating role of structural empowerment." European Management Journal, Vol. 38 No. 1: 169-178.

Andrews, D.R., Richard, D.C.S., Robinson, P., Celano, P. and Hallaron, J. 2012. "The influence of staff nurse perception of leadership style on satisfaction with leadership: a cross-sectional survey of pediatric nurses." International Journal of Nursing Studies, Vol. 49 No. 9: 1103-1111.

Barrington, F., Harrington, D.M. 1981. "Creative intelligence and personality." Annual Review of Psychology, 32: 439-478.

Baytcom. 2015. "Bayt: the advantages no disadvantages of working from home" https://www.bayt.com/en/career-article-1601/

Bloom, N. 2014. "To Raise Productivity, Let more Employees Work from Home." Harvard Business Review, 92(1/2): 28-29.

Bruce, L. 1998. "Understanding the Power, Responsibility, Leadership and Learning:the key to successful Knowledge management." Journal of Systemic Knowledge Management.

Chin, W. 2010. "How to write up and report PLS Analyses." In Handbook of Partial Least Squares Analysis: Concepts, Methods and Applications. Berlin, Heidelberg: Springer.

Choudhury, Prithwiraj, Cirrus Foroughi, and Barbara Larson. 2019. "Work-From-Anywhere: The Productivity Effects of Geographic Flexibilit." SSRN research paper.

Clark, S.C. 2000. "Work/ family Border Theory: A New Theory of Work/ family balance." Human Relations, 53(6): 747-770.

Cohen L, Manion L, Morrison K. 2013. "Research methods in education”, Routledge.

Cowden, T., Cummings, G. and Profetto-McGrath, J. 2011. "Leadership practices and staff nurses' intent to stay: a systematic review." Journal of Nursing Management, Vol. 19 No. 4: 461-477.

Crosbie, T., \& Moore, J. 2004. "Work-life Balance and Working from Home." Social Policy and Society, 3(3), 223-233. https://doi.org/10.1017/S1474746404001733

Dahlin, K., Taylor, M., Fichman, M. 2004. "Todays Edisons or weekend hobbyists: Technical merit and success of inventions by independent inventors." Research Policy, 33(8):1167-1183

De Jong, J., Von Hippel, E.A., Flowers, S. 2010. "Comparing Business and Household Sector Innovation in Consumer Products: Findings from a Representative Study in the UK" (September 27), Working Paper. Available at SSRN: http: ssrn.com/abstract $=1683503$.

Ellison, N., Steinfield, C., \& Lampe, C. 2007. "The Benefits of Facebook "Friends": Exploring the Relationship Between Collage Student Use of Online Social Networks and Social Capital." Journal of Vomputer-Mediated Communication, 12 (3) 
Farrell, K. 2017. "Working from Home: A Double-Edged Sword.” Home Renaissance Foundation Conference 16-17 November, London. doi.org/10.21427/kk4b-e646

Ferdinand, A. 2006. "Metode Penelitian Manajemen". Semarang: Badan Penerbit Universitas Diponegoro.

Fornell, C. \& Larcker, D.F. (1981). Evaluating structural equation models with unobservable variables and measurement error. Journal of Marketing Research: 39-50.

Forsyth, D. R. 2010. "Group Dynamics (5th Ed)." Wadsworth: Cengage Learning.

Ghozali, Imam. 2014. "Structural Equation Modeling, Metode Alternatif dengan Partial Least Square (PLS)." Edisi 4. Semarang : Badan Penerbit Universitas Diponegoro.

Grant, C.A., Wallace, L.M. and Spurgeon, P.C. 2013. "An Exploration of the Psychological Factors Affecting Remote e-worker's Job Effectiveness, Well-being and Work-life Balance." Employee Relations, 35(5) :527-546, https://doi.org/10.1108/ER-08-20120059

Harker, M.B. and MacDonnell, R. 2012. "Is Telework Effective for Organizations? A Metaanalysis of Empirical Research on Perceptions of Telework and Organizational Outcomes." Management Research Review, 35(7): 602-616.

Jeppesen, L.B. and Lakhani, K.R. 2010. "Marginality and problem-solving effectiveness in broadcast search." Organization Science. 21(5): 1016-1033.

Jones, R. A., Jimmieson, N. L., \& Griffiths, A. 2005. "The impact of organizational culture and reshaping capabilities on change implementation success: the mediating role of readiness for change." Journal of Management Studies, 42(2): 361-386.

Kossek, E.E., Lautsch, B.A. and Eaton, S.C. 2006. "Telecommuting, Control, and Boundary Management: Correlates of Policy Use and Practice, Job Control, and Work-family Effectiveness." Journal of Vocational Behavior, 68(2): 347-367.

Kurland, N. and Bailyn,, L. 1999. "Telework, The Advantages and Challenges of Working Here, There, Anywhere and Anytime, Organisational Dynamics, Autumn" : 53-68.

Kwon, K. and Kim, T. 2020. "An integrative literature review of employee engagement and innovative behavior: revisiting the JD-R model." Human Resource Management Review, Vol. 30(2).

Lakhani, K.R., Wolf, R.G. 2005. "Why Hackers Do What They Do: Understanding Motivation and Effort in Free/Open Source Software Projects", in: J. Feller, B. Fitzgerald, S. Hissam, and K. R. Lakhani (eds.). Perspectives on Free and Open Source Software, MIT Press: Cambridge, Mass: 3-22.

Larson, B. 2020. "Companies Can Help Employees Working Remotley During The Covid-19 Pandemic." https://news.northeastern.edu/2020/03/12/heres-how-companiescan-help-employees-working-remotely-in-light-of-the-covid-19-pandemic/

Li, Z., Gupta, B., Loon, M. and Casimir, G. 2016. "Combinative aspects of leadership style and emotional intelligence." Leadership and Organization Development Journal, Vol. 37 No. 1: 107-125.

Luppicini, R. 2007. "Review of computer mediated communication research for education." Instructional Science, 35(2): 141-185.

Madjar, N, Oldham, G.R, Pratt, M.G. 2002. "There is no place like home? The contributions of work and non work creativity to employees' creative performance". Academy of Management Journal, 45(4): 757-767

Mann, S. and Holdsworth, L. 2003. "The Psychological Impact of Teleworking: Stress, Emotions and Health", New Technology, Work and Employment, 18(3): 196-211.

Merdian, H. L., \& Warrior, J. K. 2015. "Effective communication between students and lecturers: Improving student-led communication in educational settings." Psychology Teaching Review, 21(1): 25-38. http://ovidsp.ovid.com/ovidweb.cgi?T=JS\&PAGE=reference\&D=psyc12\&NEWS=N\&AN $=2015-40359-004$

Mirchandani, K. 2000. “The Best of Both Worlds' and 'Cutting My Own Throat': contradictory Images of Home-based Work." Qualitative Sociology, 23(2): 159-182.

Moran, S. 2016. "Digitally Mediated Communication." Ethical Ripples of Creativity and Innovation : 214-222. https://doi.org/10.1017/9781108954105.024 
Narpati, B., Meutia, K, I., Ningrum, E, N. 2021. "Produktivitas Kerja Pegawai yang Dipengaruhi oleh Work From Home (WFH) dan Lingkungan Kerja Selama Masa Pandemi". Jurnal IImiah Manajemen Forkama, Vol 4(2): 121-133.

Nilles, J.M. 2007. "Editorial: the future of e-work." The Journal of E-Working, 1(1): 1-12.

Nytimescom. 2013. "NY Times Sunday Review editorial: Location, Location, Location"' available at NY Times .com/2013/03/03/ accessed 25/8/17

Orgambidez, A. and Almeida, H. 2020. "Exploring the link between structural empowerment and job satisfaction through the mediating effect of role stress: a cross-sectional questionnaire study." International Journal of Nursing Studies, Vol. 109.

Pamela, S. J., Cynthia, C. M., Strohfus, P., \& Marcia, B. 2012. "Using Transformational Change to Improve Organizational Culture and Climate in a School of Nursing." Journal of Nursing Education, 51(2): 81-88.

Pathak, A.A., Bathini, D.R., Kandathil, G.M. 2015. "The Ban on Working from Home Makes Sense for Yahoo. It needs the Innovation and Speed of Delivery that come from Officebased Employees." Human Resource Management International Digest, 23(3): 12-14.

Rahi, S. 2017. "Research Design and Methods: A Systematic Review of Research Paradigms, Sampling Issues and Instruments Development." International Journal of Economics \& Management Sciences, 6(2). https://doi.org/10.4172/2162-6359.1000403

Sauermann, J. 2016. "Performance measures and worker productivity". IZA-World of Labor. https://wol.iza.org/uploads/articles/260/pdfs/performance-measures-and-workerproductivity.pdf

Schrotenboer, B. 2020. "Working at Home had a Positive Effect on Productivty during the Pandemic", Survey Says. USA Today. https://www.usatoday.com/story/money/2020/05/04/coronavirus-pandemic-might-gamechanger-working-home/3061862001/

Spreitzer, G.M. 1996. "Social structural characteristics of psychological empowerment." Academy of Management Journal, Vol. 39 No. 2, : 483-504.

Srithongrung, A. 2011. "The Causal Relationship among Transformational Leadership, Organizational Commitment and Employee Effectiveness." International Journal of Public Administration, 34(6): 376-395.

Sullivan, C. 2003. "What's in a Name? Definitions and Conceptualizations of Teleworking and Work at Home." New Technology, Work and Employment, 18(3), : 158-165.

Timbal, A. and Mustabsat, A. 2016. "Flexibility or Ethical Dilemma: An Overview of the Work from Home Policies in Modern Organizations around the World." Human Resource Management International Digest, 24(7)

Tolmie, Andrew \& Boyle, James. 2000. "Factors influencing the success of computer mediated communication (CMC) environments in University teaching: a review and case study." Computers \& Education. 34. 119-140. 10.1016/S0360-1315(00)00008-7.

Von Hippel, E. 1988. "The Sources of Innovation", Oxford: Oxford University Press.

Weinbaum, C., Girven, R., \& Oberholtzer, J. 2016. "The Millennial Generation."

Williams, J. C. 2020. "The Pandemic Has Exposed the Fallacy of the "Ideal Worker." Harvard Business Review. https://hbr.org/2020/05/the-pandemic-has-exposed-thefallacy-of-the-ideal-worker

Zhang, X. M., \& Bartol, K. M. 2010. "Linking empowering leadership and employee creativity: The influence of psychological empowerment, intrinsic motivation, and creative process engagement." Academy of Management Journal, 53(1), 107-128.

Zhou, X., Ma, J. and Dong, X. 2018. "Empowering supervision and service sabotage: a moderated mediation model based on conservation of resources theory." Tourism Management, Vol. 64, : 170-187. 